\title{
MEMÓRIAS DE ALFABETIZAÇÃO: A CULTURA ESCOLAR EM FOCO*
}

Cancionila Janzkovski Cardoso (UFMT/UFR)

Este texto faz uma incursão pelos labirintos da memória. As perguntas que o motivaram foram: quando rememoram seus processos de alfabetização, de que lembram os/as professores/as? O que ficou mais vívido em suas memórias? A professora, a cartilha, os cadernos, as lições, os materiais, os colegas, a merenda, as brincadeiras, as punições? Do que não lembram?

O objetivo da pesquisa é sistematizar as memórias de alfabetização de um grupo de professores/as do Curso de Aperfeiçoamento UFR/SEMED 2020 , com vistas a situá-las no contexto da cultura escolar do campo da alfabetização.

A perspectiva adotada é a da história cultural, que entende que a memória do "homem comum" - recordações familiares, histórias locais, recordações pessoais e, no caso desta pesquisa, em especial, recordações escolares -, de algum modo representam a consciência coletiva de grupos inteiros e, portanto, podem alimentar a história e por ela ser consideradas (LE GOFF, 2003). Assim, as memórias permitem uma aproximação com tempos, espaços e sujeitos diferentes de alfabetização, que contam uma história da alfabetização, saberes e modos de fazer que constituem a cultura escolar.

\section{Procedimentos metodológicos}

Os dados analisados são oriundos de uma tarefa escrita, proposta pelo módulo Ensino e Metodologia da Língua Portuguesa I, do Curso de Aperfeiçoamento da Secretaria Municipal de Educação de Rondonópolis (SEMED), oferecido pela Universidade Federal de Rondonópolis (UFR), em 2020. Devido à crise sanitária-pandêmica, o curso, que inicialmente previa uma carga horária presencial, complementada por atividades a distância, passou a ser totalmente na modalidade ensino a distância, notadamente pelo uso de aulas gravadas, podcast e lives.

Após trabalhar com os conceitos de Alfabetização e Letramento, no papel de uma das professoras do módulo, propus como tarefa a escrita das

${ }^{*}$ DOI - 10.29388/978-65-86678-68-0-0-f.199-220 
Memórias de Alfabetização, a partir da seguinte orientação como "evocadora da memória":

1. Escreva as memórias mais relevantes de seu processo de alfabetização.

2. Você pode citar: a data, o lugar onde se alfabetizou: nome do estado, município e escola; o nome de sua alfabetizadora; a cartilha ou outros materiais utilizados; o método/metodologia de trabalho; como eram as aulas; como você se sentia naqueles tempos; o incentivo ou as punições que teve; músicas que cantava; brincadeiras; cadernos; exercícios, outros livros lidos, etc...

3. Enfim, fique à vontade para mencionar o que the parecer relevante ou contar alguma história marcante.

4. Se possível, aponte as mudanças e as permanências que ocorreram nas práticas de alfabetização.

O recorte analisado considerou, de forma aleatória, $20 \%$ das respostas dos/as 248 professores/as inscritos/as no curso, a partir dos seguintes filtros:

a. Devido ao tempo restrito para a elaboração deste texto, a coleta de dados se estendeu até que $50 \%$ dos cursistas tivessem enviado seus depoimentos no AVA da UFR, o que totalizou 124 textos;

b. Destes, foram separados os que responderam autorizando o uso das informações pela professora/pesquisadora, somando 99 textos;

c. Do grupo que autorizou, foram eleitos os $20 \%$, seguindo a ordem alfabética da primeira letra do nome. Assim, estão contemplados os relatos dos autores cujos nomes têm como inicial a letra $A$ até a letra L, totalizando 49,6 - arredondados para 50 textos memorialísticos.

Para a sistematização, utilizei a análise de conteúdo (Bardin, 2002), fazendo a leitura - imersão nos dados - e vislumbrando algumas categorias mais recorrentes. A elaboração e utilização de uma planilha Excel, com recortes dos depoimentos, permitiu uma visão de conjunto, para exploração 
dos dados mais emblemáticos. A tentativa foi identificar e agrupar certas constantes, reveladas nos textos.

\section{Alguns pressupostos teórico-metodológicos}

O estudo foi norteado por pesquisas e concepções da Nova História Cultural, "corrente histórica que subverte não só o domínio tradicional da história, mas também o das ciências humanas (ou sociais) e inclusive, sem dúvida, todo o campo do saber" (LE GOFF, 2001, p. 16). Esta nasceu a partir dos Annales, uma revista de história econômica e social, criada por Lucian Febvre e Marc Bloc, na França, em 1929, depois denominada Escola dos Annales. Nascida de uma certa revolta à história positivista do século XIX, centrada nos grandes feitos e heróis, a Nova História Cultural ampliou o campo, trazendo novas problemáticas, novos sujeitos e novos objetos. Uma pergunta que ecoou no início da constituição dessa corrente foi: afinal, "a história do homem cotidiano não é tão significativa e dramática quanto dos grandes homens?" (LE GOFF, 2001, p. 16).

Assim, nessa vertente a história traz a lume os homens comuns, as mulheres, seus modos de vestir, de comer, a religião, a história oral, entre outros aspectos da vida cotidiana.

No caso da história da educação (e da alfabetização), antes concentrada em documentos oficiais escritos (leis, decretos), sob a influência da Nova História, relevam-se fontes até então consideradas sem nenhum prestígio: memória de professores e alunos, cartilhas escolares, livros didáticos, cadernos escolares, métodos e práticas etc. Nova história, novos sujeitos, novos objetos, tendo como pressuposto a compreensão de que a realidade social é culturalmente construída.

Assim, para Lucian Febvre, a história não deve ser o registro da sequência de acontecimentos baseada apenas em documentos escritos, mas deve se valer de documentos não escritos e fazer conexões com outras ciências, abordando todos os aspectos da atividade humana.

Destaco aqui a história oral como elemento de registro da história e de valorização da memória e, no caso específico desta pesquisa, os depoimentos escritos de história vivida no processo de alfabetização.

Como disse, nossa memória tem conexão com a memória de um grupo - a consciência coletiva de um grupo. Daí, como sugere Rousso (1996), o que se revela não é individual, mas a memória de um indivíduo inserido num contexto familiar, social, nacional. Aqui se entende, portanto, 
memória como uma "reconstrução psíquica e intelectual que acarreta uma representação seletiva do passado" (ROUSSO, 1996, p. 94).

Nesse sentido, "o ato mnemônico fundamental é o 'comportamento narrativo', que se caracteriza antes de mais nada pela sua função social, pois se trata de comunicação a outrem de uma informação, na ausência do acontecimento ou do objeto que constitui o seu motivo" (LE GOFF, 2003, p. 421 , grifo do autor). A memória é, portanto, imprescindível para revelar práticas históricas de alfabetização.

E, para compreender essas práticas, é primordial lançar mão do conceito de culturas escolares, que tomo emprestado de Viñao Frago:

[...] um conjunto de teorias, ideias, princípios, normas, modelos, rituais, inércias, hábitos e práticas (formas de fazer e pensar, mentalidades e comportamentos) sedimentadas ao longo do tempo em forma de tradições, regularidades e regras de jogo que se transmitem de geração em geração e geram estratégias de atuação (VIÑAO FRAGO, 2007, p. 87).

Assim, boa parte do que professores e professoras aprendem para atuar advém das culturas escolares, aprendidas em contexto. Além disso, essas culturas escolares estão associadas a crenças seculares, fortemente enraizadas na profissão, que orientam a experiência da escola (escolarização), e são bastante resistentes à mudança (VIÑAO FRAGO, 2007).

Por longos anos, as classes de alfabetização foram assumidas por professores/as iniciantes, sem experiência, recém-contratados/as e, portanto, suas práticas só podiam estar fortemente ancoradas nas culturas escolares, aprendidas durante o período em que foram alunos.

Dominique Julia (2001), outro autor que discute cultura escolar, definindo-a como um conjunto de normas e práticas, pondera que o estudo mais tradicional da escola é o das normas que as regem, já que atingimos mais facilmente os textos reguladores e os projetos pedagógicos que as realidades, ou seja, as práticas. Pensar em práticas nos leva diretamente à profissionalização dos professores: quais são os saberes e o habitus requeridos de um/a professor/a?

Nesta pesquisa nos aventuramos em saber quais eram os saberes e as práticas mais comuns aos/as alfabetizadores/as de nossos/as cursistas. 


\section{Sobre o contexto da alfabetização}

Muitas palavras foram ditas. Trata-se de um grupo que se alfabetizou entre os anos de 1968 a 1997, com maior concentração nas décadas de 1980 e 1990. Estamos focando, portanto, cerca de três décadas de práticas de alfabetização, que abrangem desde a constatação e as grandes críticas ao fracasso escolar que ocorria na passagem da primeira para a segunda série do ensino seriado (1970 em diante), até as primeiras tentativas da escola organizada em ciclos (1990 em diante), proposta embasada na discussão e divulgação de inúmeras ideias pedagógicas, oriundas de diversas ciências humanas, como a Sociologia e a Antropologia, a Psicologia, a Psicolinguística, a Linguística Aplicada, a Filosofia da Linguagem e a Análise do Discurso.

No campo político, o período abrange a ditadura militar, iniciada em 1964, a abertura política que culmina em 1988 com a promulgação da Constituição Cidadã e os anos 1990, em que o País vivia ares de liberdade e fortalecimento da democracia.

Não faz parte do escopo deste trabalho a recuperação da história da alfabetização no Brasil, no entanto, posso citar alguns fatos marcantes ocorridos nas décadas de 1980 e 1990: Emilia Ferreiro e Ana Teberosky publicam o livro "Psicogênese da Língua Escrita" (1985), no qual sistematizam uma teoria que veio a influenciar fortemente a alfabetização no Brasil; Magda Soares publica o texto "As muitas facetas da Alfabetização" (1985) e o livro "Linguagem e Escola: uma perspectiva social" (1986), que se tornam clássicos no campo da alfabetização e linguagem; João Wanderlei Geraldi influencia o ensino da Língua Portuguesa (e da alfabetização) com a proposta do texto como unidade de ensino, publicando o livro por ele organizado, "O texto na sala de aula" (1984); Ana Luiza Smolka publica sua tese de doutorado, "A criança na fase inicial da escrita: a alfabetização como processo discursivo" (1988); após longa discussão, são publicados os Parâmetros Curriculares Nacionais (1997), que procuram dar um direcionamento nacional a todas as áreas de ensino e estão vigentes até hoje; o Ministério da Educação reorganiza a avaliação do Programa Nacional do Livro Didático, adequando-a aos novos propósitos da educação (1996).

Neste período, passamos das propostas de um ensino mecânico e associacionista - vigentes até meados da década de 1980 - calcado em letras, sons e sílabas, que considerava a escrita como código, com as crianças chegando, no máximo, ao final do primeiro ano, à leitura e escrita de palavras, para um ensino mais preocupado com as aprendizagens dos alunos, 
sujeitos ativos, no qual a escrita é concebida como sistema de representação, e calcado na apresentação dos chamados textos reais, com possibilidades de experimentação na escrita por meio de textos espontâneos.

O contexto de alfabetização dos sujeitos desta pesquisa se deu, portanto, enquanto este caldo cultural, teórico e pedagógico se formava e se avolumava, num cenário político que, aos poucos, caminhava para a restauração da democracia. No que concerne à alfabetização, foram muitas as mudanças teóricas, didáticas e pedagógicas propostas, tanto na formação dos professores, como nas políticas dos estados e municípios e nos livros didáticos.

\section{Origem dos participantes}

Além de Mato Grosso, - e especificamente das cidades de Rondonópolis, Guiratinga, Tabaporã, São José do Povo, Jaciara, Poxoréo, Araputanga, General Carneiro e Alto Araguaia -, mais sete estados do Brasil são apontados como a origem do nascimento e início da escolarização dos depoentes, conforme gráfico a seguir:

Figura 1 - Estado onde se alfabetizaram

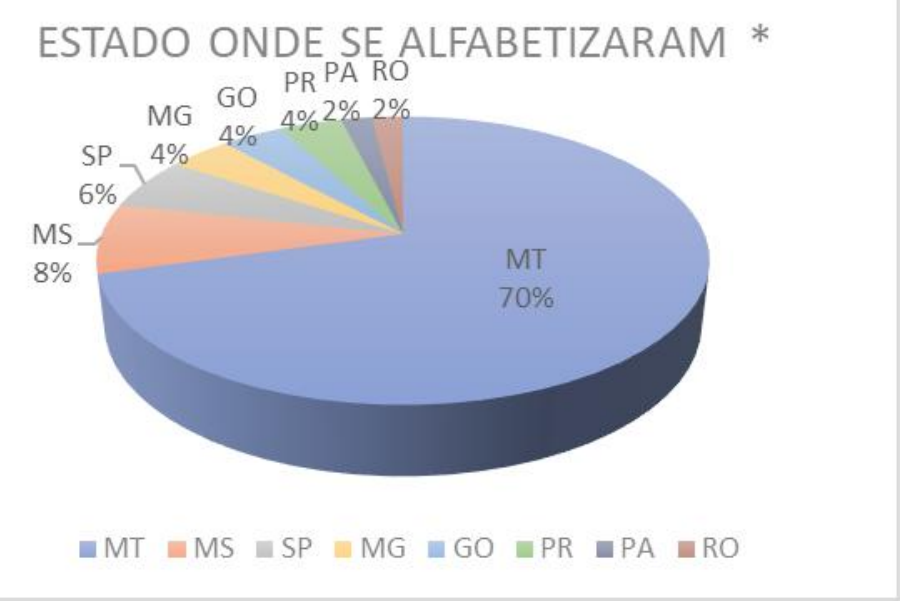

Fonte: Dados da pesquisa

* Uma pessoa informou dois estados: começou a 1a Série em Goiás e terminou em Mato Grosso.

Desse modo, temos $70 \%$ de pessoas mato-grossenses e $30 \%$ de pessoas oriundas de outros estados. Os relatos dos que são migrantes apontam 
a mudança para Mato Grosso, entre outras razões, como tentativa de meIhorar a vida, na busca pelo garimpo ou emprego em fazendas e, ainda, se juntar a outras pessoas da família que aqui estavam estabelecidas.

Chama a atenção a grande quantidade de pessoas que têm origem rural, iniciando seus estudos em classes multisseriadas:

Meu nome é ASC fui alfabetizada no ano de 1992-1993 na zona rural na fazenda Paulicéia: Escola Rural Mista Dona Jovina Santana Pugliese no município de Rondonópolis, no estado de Mato Grosso. Naquela época, minha escola era multisseriada, ou seja, eram quatro séries numa sala só e por apenas uma professora (ASC) ${ }^{1}$.

Quando penso no meu processo de alfabetização me remeto à zona rural. Por volta de 1998 meus pais se mudaram para uma fazenda, a 80 km de Rondonópolis, meu pai operador, de máquina agrícola, e minha mãe, dona de casa (DOM).

\section{0 que lembram as/os professores/as sobre seus processos de alfabetização?}

As reações dos/as cursistas à necessidade de escrever um texto sobre suas memórias foram as mais diversas. Uns lembram, perfeitamente, de detalhes, nomes, materiais, cheiros e cores... Outros alegam que tudo se apagou da memória, que não há lembrança alguma, mas, gradativamente, colocam alguns pontos. Uns se dedicam com afinco e explícito prazer, colocando, inclusive, fotos de criança; outros demonstram pouco investimento; uns evidenciam alegria em relembrar; outros recordam de coisas tristes e marcantes.

\section{O vir a ser alfabetizado(a): sonho e luta}

Crianças que nascem em uma sociedade grafocêntrica cedo percebem a necessidade de aprender a ler e escrever e para ela são impulsionadas. Seja porque vejam cotidianamente os adultos da família ou outras crianças manipulando impressos, seja porque vêm os irmãos mais velhos indo à escola, ou porque são desafiadas por folhetos, placas, propagandas impressas ou projetadas na TV, o desejo de aprender a ler e escrever aparece cedo. $\mathrm{O}$ desafio dessa aprendizagem é uma constante nos relatos:

\footnotetext{
${ }^{1}$ Para manter o anonimato, optei por utilizar as iniciais do nome dos/as depoentes.
} 
Com cinco anos de idade eu tinha muita vontade de aprender a ler, um dia, eu estava na igreja e sentaram duas meninas, já alfabetizadas, ao meu lado e começaram a ler, quando uma delas me perguntou se eu sabia ler, eu respondi que sim, mas que não queria gastar saliva (que no momento eu disse guspe mesmo kkkk), fiquei com vergonha de dizer que eu era analfabeta kkk (ACNA).

Lembro que eu era encantada com a escola, queria muito ir à escola e, por isso, ficava sempre junto com meus irmãos quando eles estavam fazendo as tarefas escolares. Eu os observava e questionava o tempo todo, os vencia pelo cansaço e assim eu aprendia. Praticamente, fui para a escola já alfabetizada tanto que a minha primeira professora até me colocava para ajudar "quem não sabia" (ECLF).

Esse desejo de muitos dos depoentes foi potencializado e estimulado por membros da família. Muitos depoimentos informam o baixo grau de escolaridade dos pais. Nesse sentido, as famílias configuravam-se como "não herdeiras" de um determinado "capital cultural", na perspectiva de Bourdieu e Passeron (1964). ${ }^{2}$

No entanto, mesmo com pouco acesso a materiais impressos, com pouca escolarização e até com muitas limitações de acesso à escola, as famílias se constituem em grandes promotoras da escolarização dos filhos, demonstrando significativos esforços, que vão desde o ensino doméstico, dentro de suas possibilidades, à valorização da escola e à viabilidade de mudança de local de moradia da família ou dos filhos para que estes pudessem estudar, até a construção de escola, como podemos constatar:

Comecei a frequentar a escola aos seis anos de idade, morava no sítio com meus pais; para que pudesse estudar, eu e meus dois irmãos fomos morar na casa de uma tia, não foi uma transição muito fácil no início (AAO).

Fui alfabetizada em casa com meu pai, lembro-me que morávamos na fazenda e enquanto ele tirava leite das vacas eu ficava sentada em

\footnotetext{
${ }^{2}$ No livro Les héritiers, les étudiantes et la culture, Pierre Bourdieu \& Jean Claude Passeron (1964), com base em uma abordagem macroestrutural, analisam os índices de produtividade escolar entre jovens franceses de distinta origem social. $O$ discurso da escola libertadora é desmistificado, pois Bourdieu explicita os mecanismos perversos e ocultos responsáveis pelas desigualdades no aproveitamento e no rendimento de estudantes pertencentes a diferentes grupos sociais.
} 
um banquinho, com um caderno, perto dele, e ele me ajudava na junção das letras para formar as palavras, com esse exercício diário, logo comecei a ler e consequentemente a escrever (JCJA).

Antes mesmo de iniciar minha vida escolar já conhecia as vogais, escrevia meu nome, do meu irmão, pai e mãe. Conseguia contar até dez, tudo ensinado em casa por minha mãe, a qual, até aquele momento, só havia estudado o quarto ano do ensino fundamental (FRBF).

Porém, em minha casa, meu pai contava histórias e causos todas as noites, somos em 7 irmãos e cada um escolhia a sua história preferida e meu pai narrava com perfeição e eu amava aqueles momentos. [...] minha mãe sabe pouco ler e escrever, meu pai só assina o nome dele, porém sabiam nos colocar para estudar e a olhar se tinha alguma nota em vermelho no boletim, meu pai sempre dizia que precisávamos estudar, que ele não tinha tido oportunidade. [...] sei que sou motivo de orgulho para meus pais, que lutaram tanto para que seus filhos pudessem estudar e, dos sete filhos, só eu concluí meus estudos, fazendo até faculdades e especialização (DSF).

Como morávamos na zona rural, longe da cidade, não pude frequentar a pré-escola, mas tinha um grande desejo de ir para a escola e aprender a ler e escrever desde muito pequena, mas só consegui frequentar a escola quando já tinha 7 anos, porque meu pai, avô, tios e vizinhos reivindicaram, junto à prefeitura, a abertura de uma escola na comunidade onde morávamos para que todas as crianças daquele lugar pudessem estudar (ERF).

O que se nota, coroando o desejo infantil de ir à escola, é a luta das famílias pela escolarização de seus filhos, contrariando o mito do desinteresse das camadas populares pela educação, ou, como caracterizou Bernard Lahire, o mito da "omissão parental" 3 .

Aparecem inúmeros investimentos por parte da família, expressos no acompanhamento do estudo dos filhos, na compra de material com muita dificuldade, na luta por vaga na escola, no apoio para levar a criança de bicicleta ou trator por quilômetros de distância, ou ainda, levar a criança a morar com parente para que essa tenha melhores condições de estudo.

\footnotetext{
${ }^{3}$ Sobre o mito da "omissão parental" ver Lahire (2004).
} 
Nessa luta, fica claro que as maiores dificuldades atingem a população da zona rural. ${ }^{4}$

Mais de uma depoente atribuiu a alfabetização ou o início dela ao pai, mesmo esse tendo baixa escolarização, aspecto bastante inusitado, pois historicamente coube às mães ensinar as primeiras noções da língua escrita às crianças. Outras, por sua vez, atribuem as primeiras aprendizagens à mãe. Há, também, quem diz que foram os irmãos ou a observação das tarefas escolares que os irmãos faziam os responsáveis pelo despertar para a leitura e escrita.

Depoimentos nessa dimensão revelam que o fracasso escolar de muitas das crianças das redes públicas de ensino não está relacionado com a "omissão parental", mas com as terríveis desigualdades enfrentadas por determinados grupos sociais.

A exemplo disso, os dados indicam que, em 1988, na zona rural do município da Araputanga - MT não havia escola para ERF estudar. Ela narra que a comunidade se reuniu e construiu "uma casinha de paredes e teto de madeira (tábuas) e chão de terra batida, ficava bem perto da minha casa. Tinha um quadro-negro pequeno e algumas carteiras de madeira, onde sentavam dois alunos em cada" (ERF). Este relato nos remete aos Relatórios de Inspetores de Mato Grosso, do século XIX: professores leigos, escolas improvisadas, troncos, tocos de árvores, palhas e lonas.

Num contexto econômico, social e educacional de exceção, aparece fortemente o esforço em romper com a reprodução das condições vividas pelas famílias, buscando na escola uma superação e uma (im)provável ascensão social.

\section{Professoras/es alfabetizadoras/es: inspiradoras/es ou nem tanto?}

Se é verdadeira a ideia comum de que "todos tiveram uma alfabetizadora", procuro, a seguir, sistematizar como são lembradas as alfabetizadoras e os alfabetizadores. Afinal, o que lembram de suas/seus alfabetizadoras/es os sujeitos desta pesquisa?

A figura do/a alfabetizador/a, quando mencionada, vem sempre seguida de um complemento, uma descrição, uma menção ao tipo físico e/ou

\footnotetext{
${ }^{4}$ Em que pesem esses esforços, muitos depoimentos revelam processos extremamente fragmentados, com constantes mudanças de cidade, de emprego, de altos e baixos nas condições financeiras da família, de trocas de escola e de professora.
} 
comportamento. Portanto, com essa breve descrição, já fica claro se o processo de alfabetização é interpretado pelos depoentes como algo tranquilo e até prazeroso ou algo traumatizante ou tumultuado.

Mais que isso, alguns depoentes falam explicitamente deste processo, a exemplo de JMSS, que ao final de seu texto escreve: "Enfim, são essas as minhas memórias mais marcantes do tempo da alfabetização. Como eu era feliz!"; ou DBPC, que já no título do texto anuncia: "Minhas trágicas memórias de alfabetização".

A condução do processo está intimamente articulada à figura do/a professor/a. Alguns depoentes citam a precariedade da escola, a falta de materiais, o pouco acesso a livros e outras lacunas, mas isso não é motivo de traumas. Já o comportamento dos professores leva diretamente à memória afetiva, às boas ou más lembranças.

Os dados revelam que, dos que se posicionaram explicitamente sobre o/a professor/a e/ou o processo de alfabetização, 37 depoentes (74\%) transmitem uma visão positiva e 11 depoentes (22\%) os ligam a comportamentos e cenas que criticam fortemente.

Desse modo, não desejando aqui alimentar uma visão maniqueísta, a leitura dos dados faz desfilar diferentes perfis desse profissional. Há os calmos, criativos, bondosos, acolhedores, mas há também os rígidos, nervosos, punitivos e até violentos. Vejamos:

Um amor de pessoa, sempre educada, alegre, tratava todos com muito carinho e amor (AAO).

Um doce de pessoa, daquelas que fica gravada na nossa mente para toda a vida... Tinha um rosto lindo (AMCA).

Uma professora bonita e com cabelo que cheirava bebê (APG).

Ela era muito paciente e ensinava com carinho, apesar de todas as dificuldades (CFS).

Uma senhora muito simpática, de lindos e cativantes olhos verdes. Não tenho à mente detalhes, mas me lembro que comecei a gostar de estudar com ela. Tanto que nunca esqueci seu nome ou seu rosto. De algum modo me sentia acolhida e respeitada por ela (DDPC).

Ela era linda, um encanto de pessoa, doce, delicada, uma fala suave e estava sempre junto da gente. Eu amava quando ela vinha na minha 
cadeira e ficava pertinho de mim. Ela sempre me elogiava, pois eu sabia fazer todas as tarefinhas que ela passava, pois eu já "sabia" ler e escrever, e assim, eu sempre era a sua ajudante (ECLF).

Ela cantava para nós todos os dias, encontro-me com ela sempre que vou visitar a minha cidade natal e ela abre um sorriso, o mesmo que carinhosamente me recebia todas as vezes que eu chegava na escola, todos os dias. Se fecho os olhos, consigo me lembrar até do gesto corporal que ela fazia: abria a porta com um sorriso no rosto, se inclinava para ficar mais acessível ao meu tamanho, cumprimentava meu pai, que sempre me levava no período vespertino e dizia: - Oi ACNA, seja bem-vinda! E me dava um abraço. (parece que estou ouvindo a voz dela... estou emocionada) (ACNA).

Lembro dos doces caseiros (que a professora trazia e comíamos com colher), de algumas brincadeiras e da voz suave da professora Mariana (IMP).

Mesmo não tendo a idade para estudar, depois da escola a professora levava nós para sua casa e nos dava almoço para depois irmos embora (FSA).

Sentia um grande afeto por ela, admirava sua sabedoria e ternura com todos. Só sei que um momento marcante me vem a memória, um sentimento de tristeza, pesar, pois antes do final do ano ela teve que se ausentar (ITB).

Professora maravilhosa. A professora era muito amorosa, e, pra mim, hoje vejo o quanto ela era inovadora, pois ensinava brincando (KCRCS).

Ela conseguia ser autoridade em sala de aula sendo completamente amável (AMQD).

Professoras carinhosas e acolhedoras, que dividem seus doces, seus lanches, seus almoços com os alunos, que os tratam bem e com respeito, que ensinam com calma e voz suave ficaram na memória e inspiram saudades a muitos depoentes. Mais que isso, algumas inspiraram a própria profissão de seus alunos.

Há, no entanto, outras memórias nada doces, que também marcaram profundamente determinados sujeitos. Muitos são os relatos de casti- 
gos e punições, de ameaças e, até, do uso de palmatória ou régua, como podemos constatar:

Me lembro perfeitamente da professora, que gritava muito, ela era muito brava [...] Nesse período [segunda série] aconteceu um episódio na sala de aula no qual ela explicava atividades de matemática e um aluno que conversava muito tirou-lhe a paciência e ela arremessou o apagador na direção do garoto e acertou-lhe em cheio na cabeça, houve muita confusão e traumas. Eu tinha tanto medo dela que nem abria a boca durante as aulas (CFS).

A Matemática é constantemente citada como motivo de traumas, mas os conteúdos de língua portuguesa também foram desafiantes para alguns sujeitos. DDPC, por exemplo, inicialmente estudou em uma escola particular em Cuiabá. Ela recorda a dificuldade em aprender a ler e como essa dificuldade irritava a professora:

Lembro-me de ter muita dificuldade de acompanhar os conteúdos. Eu fingia saber ler, pegava os livros ou qualquer coisa com palavras e criava uma história, que supostamente estava sendo lida por mim. Mas realmente aprender a ler, eu não sabia. [...] Ela era uma senhora de cabelo bem curto, acima do peso, com sotaque da cuiabania bem acentuado. Ela brigou comigo, disse que se matava de explicar e eu nunca aprendia. Me pegou pelo braço, me levou até a lousa e me forçou contra ela. Sinceramente não sei dizer se havia alguma resposta lá. Alguma coisa escrita. Mas é viva a memória de ser pressionada contra a lousa (DDPC).

Esse episódio a fez desistir da escola naquele ano. Matriculada em outra escola no ano seguinte, encontrou acolhida por parte da professora. Mas, comenta que sempre teve dificuldade e que só na faculdade descobriu que tem dislexia.

E por que os alunos eram punidos? Há quem reflita sobre isso:

$\mathrm{Na}$ escola éramos sempre punidos pelo professor, por motivos banais: conversar em sala, errar a lição, discussões entre colegas, ele judiava muito dos alunos, é a parte ruim das minhas lembranças, mesmo assim eu gostava dele e ele morava na minha casa, porque lá não tinha lugar para ele morar (ERF). 
O caso mais emblemático e extremo é de ADSA, que assim descreve seu professor: "sujeito sem coração". Ela conta que,

Certo dia, na sala de aula, por motivo que eu como uma professora considero covarde, monstruoso e autoritário, o professor me pediu para sair de perto de minha prima e sentar ao lado de outro primo; como queria ficar do lado de minha prima, resisti e não fui. Lembro que ele me levou para fora da sala de aula, tirou uma vara de um pé de goiaba que tinha ao lado de um rego d'água, usou violência e força para me bater. Naquela época estava com uns furúnculos pelo corpo onde foram machucados e me deixando totalmente ensanguentada! Quando cheguei em casa, lembro da revolta que meu pai ficou, e cuidou de minhas feridas com muito cuidado. [...] Hoje, além das lembranças em minha mente, tenho grandes cicatrizes pelo corpo que foram causadas pela violência de um professor, machucando e arrebentando os furúnculos que eu tinha naquela época (ADSA).

Este caso se deu em uma fazenda, propriedade do pai da depoente, no município de Rio Verde - GO, em 1968, numa sala multisseriada, da qual o professor era pago pela prefeitura. O pai de ADSA solicitou imediato afastamento do professor.

Muitos são os relatos de punições, castigos e humilhações. Os mais "leves" são os que aconteceram com os outros - sempre algum menino que não queria fazer nada -, materializados no "ficar sem recreio".

As discussões sobre a utilização de castigos físicos na educação de crianças e jovens já apareciam em obras de grandes pensadores séculos XV a XIX, como: Comenius (1592-1670), Rousseau (1712-1778), Condorcet (1743-1794), Pestalozzi (1746-1827), Herbart (1776-1805), que os rechaçavam, qualificando-os como práticas antipedagógicas e pouco civilizadas. No Brasil, este tema foi normatizado pela Lei Imperial de 15 de outubro de 1827. Nela fica determinado que os castigos aplicados nas escolas deveriam se basear no método Lancasteriano, o qual refutava as punições físicas, substituindo-as pelas de cunho moral, que incitava a vergonha e o embaraço nos alunos. Por anos, várias discussões apontavam para o fato de que os castigos físicos estavam proibidos, pois representavam uma prática agressiva, que produzia aversão à escola nos alunos, reproduzia a violência e não se coadunava com um país civilizado.

Aos poucos, em especial nas primeiras décadas do século $\mathrm{XX}$, com o Movimento da Escola Nova, as "listas de castigos morais" foram 
substituídas por discussões pedagógicas, com vistas a construir uma aula atrativa, na qual o aluno fosse o centro, seus interesses o norte do processo de ensino e, portanto, não haveria necessidade de castigos, pois não haveria indisciplina.

Esse brevíssimo histórico ${ }^{5}$, nos faz ver que, em pleno final do século $X X$, os depoimentos indicam que elementos da cultura escolar aparecem como extremamente sedimentados, reeditando comportamentos já amplamente condenados e proibidos pela legislação, mas vivos e atuantes em certas práticas escolares.

Os/as depoentes sempre contrapõem uma experiência ruim com outra muito compensadora, orquestrada por professoras acolhedoras. A própria ADSA relata que teve uma segunda experiência, completamente diferente:

\begin{abstract}
Agora, falando da segunda experiência, quero dizer que foi de prazer e alegria, estudei aqui em Rondonópolis no Colégio Sagrado Coração de Jesus e tinha como professora a Olívia (Olivinha) como era chamada pelos outros professores. Era atenciosa e carinhosa com seus alunos, nunca vou esquecer seu jeito, sua voz, seu olhar e sua compreensão com as crianças. Tenho boas recordações e saudades de um tempo que não volta mais (ADSA).
\end{abstract}

Essa parte dos depoimentos fez levantar, com muita força, a questão afetiva no processo de alfabetização. Essa dimensão é a menos estudada e detalhada em pesquisas entre nós. Mas, hoje entendemos que a alfabetização possui muitas dimensões - técnica, pedagógica, política, social, cultural, ética, estética - e que a dimensão afetiva compõe com essas a complexidade desse processo. Para refletir sobre isso, dou voz a uma das depoentes:

Hoje com outro olhar, penso que o que faltou na época foi afetividade, pois nós éramos tão pequenos, era o começo de tudo, então eu penso que o professor do primeiro ano tem que ter essa consciência e tem que gostar muito do que faz, pra não deixar marcas tão negativas nas crianças, tem que ser uma pedagogia que encanta, que motiva os pequenos a lerem, a querer aprender, e também penso que o alfabetizador tem que ter muita paciência, mas

\footnotetext{
${ }^{5}$ Para aprofundamento neste tema, sugiro a tese de Rita de Cássia Souza, "Não premiarás, não castigarás, não ralharás...": dispositivos disciplinares em Grupos Escolares de Belo Horizonte (1925-1955), 2006.
} 
muita mesmo, pois tem crianças que chegam muito imaturas na escola, que não sabem pegar no lápis muito menos copiar da lousa. Então, penso que nos primeiros dias o professor precisar se conectar com seus alunos, transmitir confiança, e principalmente afeto, pois crianças aprendem mais quando gostam de seus professores e da escola, esta é uma opinião minha (DKSL).

Felizmente, as lembranças de punições e castigos são utilizadas pelos depoentes como contraexemplos, ou seja, algo que nunca farão com seus alunos, sinalizando para o rompimento de certas tradições da cultura escolar.

\section{Práticas, métodos e materiais}

A memória que os depoentes possuem de seus/suas alfabetizadores/as, além de vinculada à índole e/ou comportamento, é muito relacionada às práticas desenvolvidas em sala de aula. Muitos rituais da cultura escolar são rememorados: o trabalho com as cartilhas, o tomar a lição, o ditado, a caligrafia, a tabuada...

A maioria dos/as depoentes se alfabetizou em um período de hegemonia do ensino memorialístico e mecânico, no qual a repetição e a cópia desempenham papel fundamental. A verificação da aprendizagem se dava por meio de leitura oral individual e ditado, além de provas regulares.

O método utilizado foi assim descrito:

Recordo que além de usar os cadernos para fazer as atividades que a professora passava na lousa, nós tínhamos uma cartilha que seguia a ordem do alfabeto em sua sequência, a primeira lição era da letra "A", a segunda da letra "B" e assim sucessivamente, com as sílabas e pequenos textos que a gente os repetia até gravar na memória e saber repetir "de cor", eu adorava fazer aquelas repetições, falar as sílabas e os textos sem olhar, me sentia tão "sabida"! (ECLF).

As alfabetizadoras se desdobravam neste universo, adaptando práticas, métodos e materiais às realidades nas quais estavam inseridas. Por um lado, na zona rural, em classes multisseriadas:

Lembro-me que tinha um quadro-negro que servia para todas as turmas, a professora nos separava por série, da primeira até o quinto ano, todos na mesma sala, era muito desafiador. Às vezes a 
professora tinha que se dividir em quatro para dar conta, lembro que às vezes ela estava passando atividade no quadro, enquanto, uma turma fazendo leitura, outra, atividades de grupo, enfim, tudo ao mesmo tempo e simultâneo. [...] A professora se dividia entre dar aula, fazer a merenda e limpar a escola (DOM).

Por outro lado, na capital, Cuiabá:

Nesta série, a minha turma tinha duas professoras, sendo que uma era responsável em trabalhar os conteúdos diários e a outra em "tomar" a tabuada e a nossa leitura, e toda quarta-feira ela adentrava em nossa sala com várias cartilhas de onde retirava as palavras, frases e os pequenos textos que tínhamos que ler [...] A partir daí ela começava a chamar cada um dos alunos e os que não conseguiam fazer a leitura ou dizer a resposta correta da tabuada que era "de cor e salteada" na linguagem que ela utilizava, eram humilhados verbalmente (ENFC).

Na maior parte das práticas lembradas se ressaltam a cópia, os exercícios, as cartilhas:

Todos os dias a professora solicitava a leitura em voz alta das famílias silábicas e dos numerais, repetidas vezes. Geralmente a tarefa de casa de português era a cópia de um texto da cartilha para o caderno e exercícios de caligrafia (BPS).

Tínhamos que copiar do quadro e sempre com a letra cursiva, não tínhamos acesso a outros livros, porque não tinha biblioteca na escola e a professora não lia e nem contava histórias (DSF).

Ela utilizava cartilhas, que não me recordo o nome, mas lembro que tinha as famílias silábicas e a professora sempre tomava leitura ao final da aula, lembro que ela utilizava o método tradicional, no entanto, não se prendia somente a ele, ela investia em muitas musiquinhas, cartazes bastante coloridos e eu adorava os momentos de roda onde todos cantavam juntos (DMOB).

Alguns sujeitos mencionam o momento tenso da avaliação:

O que sempre me apavorou era a temida hora que a professora colocava uma cadeira na porta dava uma atividade e enquanto isso chamava um a um para tomar a lição (JSTR). 
A professora usava os métodos tradicionais, tomava nossa leitura do alfabeto e dos números pelo menos uma vez por semana, chamava cada um em sua mesa, geralmente no início da aula. Pedia para lermos no quadro palavrinhas e frases simples (APS).

Alguns depoimentos apontam para mudanças nas práticas, com a introdução de música e literatura. As festas cívicas e escolares são apontadas como momentos marcantes:

As aulas eram sempre muito alegres, pois sempre tinha música ao fundo, dependendo do momento, era calma ou agitada. Fazíamos passeios fora dos muros da escola, íamos na praça que era bem perto [...] Para a festa de final de ano todos participamos de uma formatura, e teve apresentação e eu fui uma das crianças que interpretei uma música do balão mágico - Galinha Magricela. Neste dia todas as meninas vestiam vestido e sapatos brancos e eu estava me sentindo a mais bela de todas, porque meu vestido era tipo de noivinha. (KCRCS).

Lembro que ela lia todo dia um livro diferente antes de começar a aula, lembro da história dos 3 porquinhos, quando ela lia eu mergulhava em minha imaginação e ficava muito concentrada e entretida, ela tinha uma voz muito suave e me passava muita segurança e empatia (APS).

Quanto ao uso de materiais, a cartilha é bastante lembrada, embora nem sempre o título o seja. A cartilha "Caminho Suave" foi citada por 14 depoentes, inclusive com alguns deles lembrando de parte de lições, ou até informando que a guardam como relicário:

"Caminho Suave", da autora: Branca Alves de Lima, 100.a Edição 1989, onde temos guardada até hoje aqui em casa essa mesma cartilha que também foi usada pela minha irmã, apesar dessa cartilha estar um pouco velha, com alguns rabiscos e algumas escritas, essa cartilha é a melhor memória do processo de alfabetização que temos (CAMC)

As outras cartilhas citadas foram: "Marcha criança"; "Toca do tatu"; "No reino da natureza"; "Porta de papel"; cartilha com abelha na capa (provavelmente "Minha Abelhinha", baseada no método fônico). O pré-livro 
para a 1a série, "Barquinho Amarelo", de lêda Dias da Silva, foi mencionado por três sujeitos. Um deles assim se manifesta:

Lembro muito bem de um livro com a capa amarelinha que tinha 3 historinhas em forma de verso, era meu orgulho, pois decorei e declamava em sala, a primeira história falava de um menino que brincava na enxurrada com um barquinho de papel, outra história falava de uma menina que achou no quintal um ovo diferente na cor azul, e a última falava de um lindo cavalo negro (DVS).

Poucos são os outros livros citados, o que evidencia um contato incipiente desse grupo com livros para além das cartilhas em seu período de alfabetização: "Os três porquinhos"; "Negrinho do Pastoreio"; "Cocota"; "Piabinha Dourada"; "João e Maria"; Livro de MT com imagens; "Mil e uma noites" e "Joelho Juvenal". Uma pessoa menciona uma biblioteca com "poucos livros de literatura" e outra, a revista Turma da Mônica. Uma pessoa, ainda, menciona um "Dicionário com capa preta".

Sabemos que o movimento de distribuição de livros de literatura nas escolas data do final da década de 1980. Segundo a Fundação Nacional do Livro ${ }^{6}$, a "Ciranda de Livros", um display plástico, com espaço para 15 exemplares, é um dos projetos de leitura pioneiros na distribuição de livros em escolas públicas carentes e na zona rural de todo o País". Este foi realizado com o apoio da Fundação Roberto Marinho e da Hoescht (de 1982 a 1985). O projeto funcionou por 4 anos, atendendo cerca de trinta e cinco mil escolas brasileiras. Em 1987, o governo federal criou o programa Sala de Leitura, semente do atual Programa Nacional de Biblioteca da Escola.

Com isso, fica explícito que a ausência de políticas públicas de distribuição de livros didáticos, literários e outros materiais incide fortemente na história da escolarização dos sujeitos.

\section{Considerações finais}

Iniciei este texto com o objetivo de sistematizar as memórias de alfabetização de um grupo de professores/as do Curso de Aperfeiçoamento UFR/SEMED 2020, com vistas a situá-las no contexto da cultura escolar do campo da alfabetização.

Alguns aspectos dos depoimentos de 50 cursistas puderam ser tratados, tais como: o lugar onde se alfabetizaram, lembranças do/a profes-

\footnotetext{
${ }^{6}$ Disponível em: http://www.fnlij.org.br/site/projetos-de-leitura.html
} 
sor/a, gestos acolhedores e punições, práticas, métodos e materiais utilizados. Relembro que os depoimentos com as recordações escolares, de algum modo representam a consciência coletiva de grupos inteiros e por isso permitiram uma aproximação com tempos, espaços e sujeitos diferentes, que contam uma história da alfabetização, saberes e modos de fazer que constituem a cultura escolar.

Outros aspectos, como as brincadeiras, o recreio, as músicas, a merenda, o racismo, os cheiros e as cores não foram contemplados, não porque não sejam importantes, mas pelo limite de espaço neste texto.

A figura do/a alfabetizador/a se destacou nestes dados, ocupando lugar central. Suas práticas, modos, crenças e concepções sobre a criança e a aprendizagem marcaram fortemente os sujeitos desta pesquisa.

Pela voz dos participantes ficou evidente a importância da vivência da criança nesta fase inicial e como ela pode ser determinante nas trajetórias escolares.

O exercício de mexer com as memórias provocou vários movimentos: a busca pela pesquisa junto à família, para relembrar histórias, ou na internet, para recuperar o título da cartilha utilizada; a busca de fotos no acervo familiar; a constatação da não lembrança, que foi muito perturbadora. Há quem se pergunte por que não se lembra e reflita sobre isso: "É mesmo estranho os fatos vividos nesta ocasião se apagarem assim. Ainda pretendo estudá-los!" (DCA).

A atividade também foi vista por alguns como oportunidade e motivação para a reflexão, corroborando os estudos no campo da Formação de Professores, que têm apontado as memórias como motor para a reflexão sobre suas práticas. Neste sentido, a tarefa foi bem acolhida: "Nunca imaginei que um dia fosse contar essa vivência da minha primeira experiência em uma escola [...] Agradeço sinceramente a professora por ter dado essa oportunidade de relatar minhas vivências durante o meu processo de alfabetização" (ADSA).

Para terminar, apresento a reflexão de uma professora, que, quando criança, encontrou pela sua frente professoras "carrancudas e sempre de mau humor":

Tenho um sonho, se me permite, vou contar...

Sonho com uma escola acolhedora, estimuladora, escola onde o que Piaget, Vigotski, Celso Antunes falam sobre a criança aos professores aconteça, onde as leis, normativas sejam efetivadas, e não somente meros discursos. Onde o aprendizado das universidades seja 
refletido, muito mais do que reproduzido [...] Uma escola para a qual Paro olharia com orgulho, e reconheceria suas palavras escritas em "Educação como exercício de Poder" (JMN).

Nossas práticas dirão se e quando faremos a proposição do autor de "transformação cultural complexa do próprio magistério" (PARO, 2008, p. 21), alterando significativamente a cultura escolar.

\section{Referências}

BOURDIEU, Pierre; PASSERON, Jean. Les héritiers, les étudiantes et la culture. Paris: Les éditions de Minuit, 1964.

BRASIL. Ministério da Educação. Secretaria de Educação Fundamental. Parâmetros Curriculares Nacionais: introdução aos parâmetros curriculares nacionais. Brasília: MEC/SEF, 1997.

FERREIRO, Emilia; TEBEROSKY, Ana. Psicogênese da Língua Escrita. São Paulo: Cortez/Autores Associados, 1985.

GERALDI, João Wanderley (org.). O texto na sala de aula. Cascavel, PR: Assoeste, 1984.

JULIA, Dominique. A cultura escolar como objeto histórico. Revista Brasileira de História da Educação, n.1 jan./jun. 2001, p. 9-43.

LAHIRE Bernard. Sucesso escolar nos meios populares: as razões do improvável. São Paulo: Editora Ática, 2004.

LE GOFF, Jacques. A História Nova, 4. ed. São Paulo: Martins Fontes, 2001.

História e Memória. 5. ed., Campinas, SP: Editora da Unicamp, 2003.

PARO, Vitor Henrique. Educação como exercício do poder: crítica ao senso comum em educação. São Paulo: Cortez, 2008. 
ROUSSO, Henry. A memória não é mais o que era. In: FERREIRA, Marieta de Moraes; AMADO, Janaína. Usos e abusos da história oral. Rio de Janeiro: FGV, 1996.

SMOLKA, Ana Luiza. A criança na fase inicial da escrita: a alfabetização como processo discursivo. São Paulo: Cortez, 1988.

SOARES Magda. As muitas facetas da Alfabetização. São Paulo. Cadernos de Pesquisa, n. 52, 1985, p. 19-24. . Linguagem e Escola: uma perspectiva social. São Paulo: Ática,1986.

SOUZA, Rita de Cássia. "Não premiarás, não castigarás, não ralharás...": dispositivos disciplinares em Grupos Escolares de Belo Horizonte (19251955). Tese (Doutorado em Educação) - Faculdade de Educação, Universidade de São Paulo, São Paulo, 2006.

VIÑAO FRAGO, Antonio. Sistemas educativos, culturas escolares e reformas. Mangualde: Edições Pedago, 2007. 